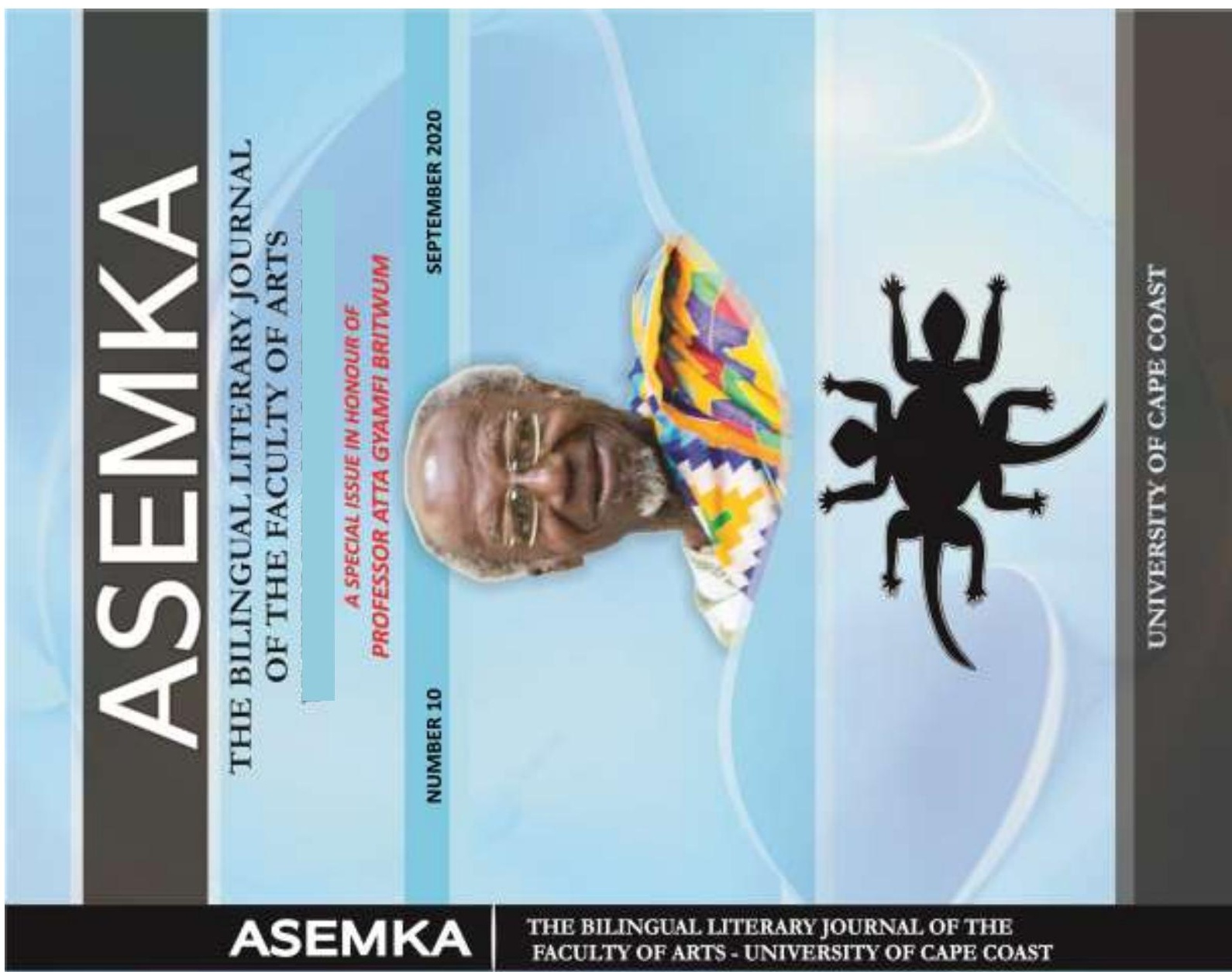





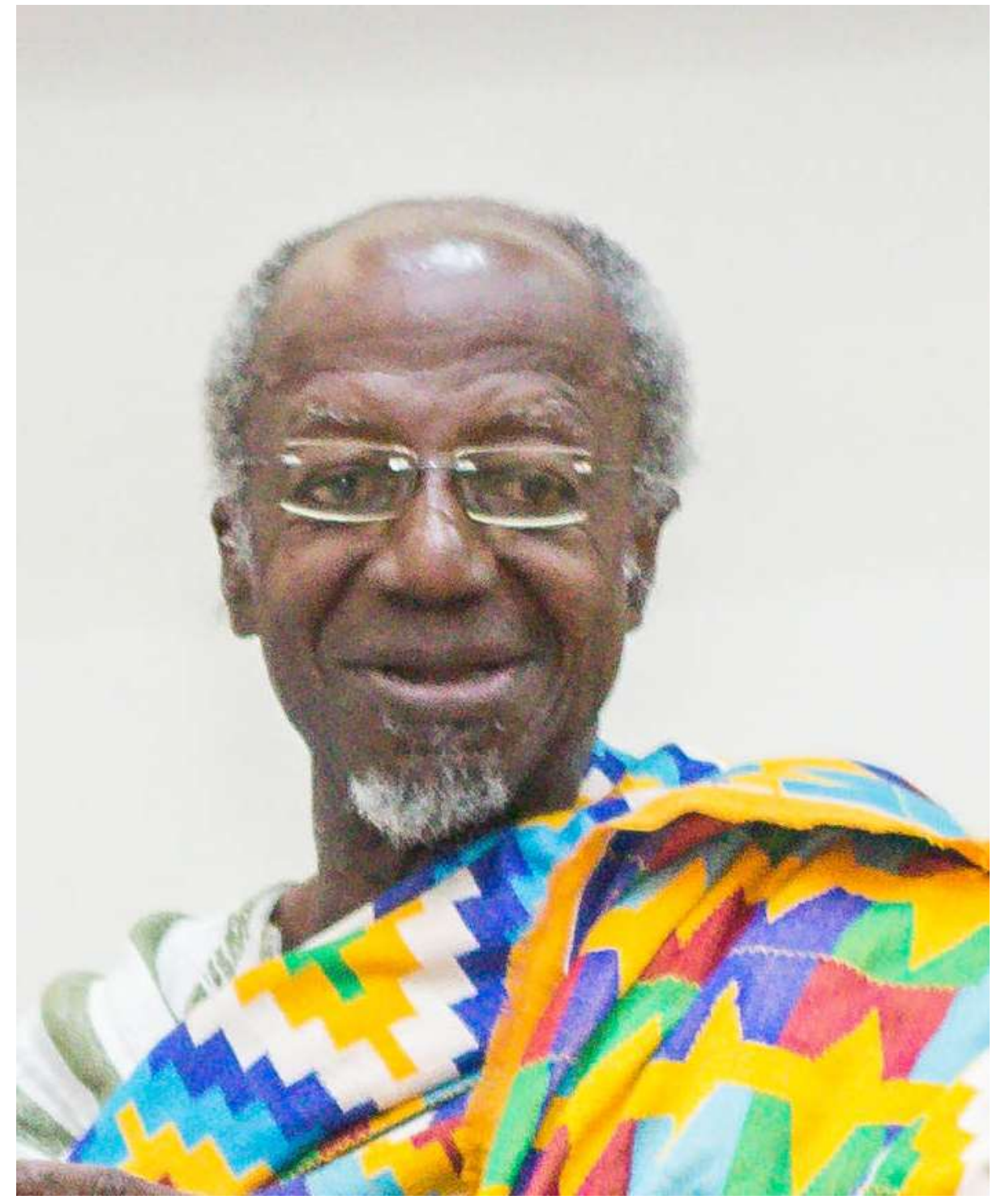
PROFESSOR ATTA GYAMFI BRITWUM 


\section{THE BILINGUAL LITERARY JOURNAL OF THE FACULTY OF ARTS UNIVERSITY OF CAPE COAST}

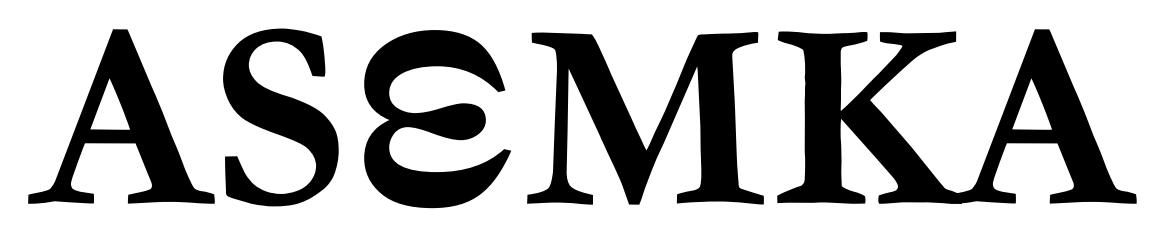

NUMBER 10

SEPTEMBER 2020

\section{EDITORIAL COMMITTEE}

Editor-in-Chief: $\quad$ Prof. Samuel Awuah-Nyamekye (Ph.D.)

Editor: $\quad$ Prof. Mawuloe Koffi Kodah (Ph.D.)

Associate Editors: Dr. Samuel Kwesi Nkansah

Dr. Mrs. Theresa Addai Munumkum

Dr. Isaac Mwinlaaru

Business Editor: Rev. Sr. Dr. Matilda Alice Nsiah

\section{EDITORIAL STAFF}

Mr. Stephen Owusu-Amoh

Mr. Isaac Kweku Grantson

\section{EDITORIAL ADVISORS}

Prof. Kwadwo Opoku-Agyemang, University of Cape Coast.

Prof. Joseph B. A. Afful, University of Cape Coast.

Prof. Raymond N. Osei, University of Cape Coast.

Prof. Richard V. Cudjoe, University of Cape Coast. 
Prof. Victor K Yankah, University of Cape Coast.

Dr. Mousa Traore, University of Cape Coast.

\section{ACKNOWLEDGEMENTS}

We acknowledge the contribution of the underlisted members of the Department of French who did preliminary editorial work on the papers:

Dr. Anthony Y.M. De-Souza (Chairman)

Prof. Raymond N. Osei

Prof. Mawuloe K. Kodah

Dr. Sylvester P. Krakue

Mr. Ofosu Addo-Danquah

Mr. Micheal Donkoh (Secretary)

\section{SUBSCRIPTION}

Ascmka is published twice in the Academic year by the Faculty of Arts, University of Cape Coast. The annual out-of-Ghana subscription rate, including air-postage, is US\$29 for individuals, and US\$ 59 for institutions and libraries. Single issue rate for individuals is US\$18. Claims for copies not received must be made within three (3) months following an issue's publication. Correspondence should be addressed to:

The Editor, Ascmka

Department of French

Faculty of Arts

College of Humanities and Legal Studies

University of Cape Coast

Cape Coast

Ghana, West Africa

Email: asemkajournal@ucc.edu.gh

\section{ADVERTISING}

Advertising rate, size specifications and related information are available upon request. Please, contact the General Editor for more information.

\section{SUBMISSIONS}

Ascmka is an internationally-refereed journal of the Humanities. It publishes scholarly and imaginative articles in Literature, Language, and Culture generally, including, Orature, Film, Theatre, Music and Art. Essays, Interviews, Book Reviews, Poetry, Short Prose Fiction and Drama are welcome. Submitted manuscripts, in English and French, must be prepared in accordance with the most recent of APA or MLA style manual, where 
applicable. The author's identity and address may appear only on the coverpage and nowhere else within the submitted manuscript. All manuscripts should be submitted electronically through:

asemkajournal@ucc.edu.gh

Manuscript will be duly acknowledged within two (2) months of receiving them. Individuals whose works are accepted for publication may provide Assmka with a brief bio-data. The Editors cannot be held liable for lost or damaged manuscripts. Material published by Assmka does not necessarily represent the views of the Journal's Editors, Staff, Financial Supporters or the University of Cape Coast and its affiliates. These parties disavow any legal responsibility related to all submitted material.

\section{BACK ISSUES}

Back issues of Ascmka that are in stock may be ordered from the Editor at US\$20 per copy.

\section{GRANT SUPPORT}

Assmka is funded through grants from the Office of the Dean, Faculty of Arts; the Publications' Board; and the Office of the Vice-Chancellor, University of Cape Coast, Cape Coast, Ghana.

No part of this Journal may be reproduced, stored in a retrieval system, or transmitted in any manner whatsoever without express permission from the Editors, except in the case of brief quotations embodied in critical Articles and Reviews.

Copyright (C2020 by The Editors and The Faculty of Arts, University of Cape Coast. The cover and page design elements were inspired by the Adinkra symbols of Ghana. 


\section{DEDICATION \\ PROFESSOR ATTA GYAMFI BRITWUM}

Professor Britwum is a man of many parts. He is as much at home with Marxist Economic Theory and Feminist Sociological Thoughts, as he is with French and Francophone Literatures. He is a great teacher and Administrator of international acclaim. The Editors dedicate this special issue of Assmka to his honour. 


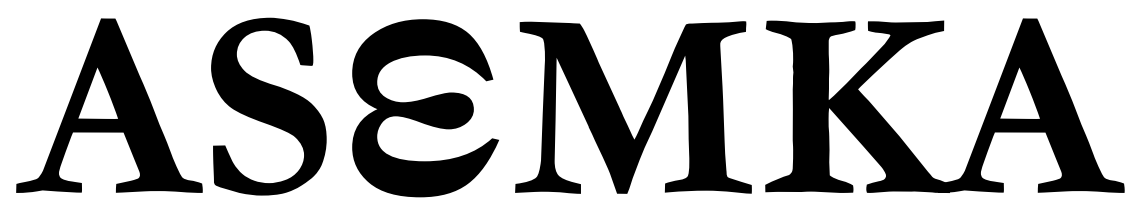

NUMBER 10

SEPTEMBER 2020

\section{CONTENTS}




\begin{tabular}{|c|c|c|c|}
\hline Editorial Committee & $\sim$ & $\sim$ & $\sim$ \\
\hline Editorial Staff & $\sim$ & $\sim$ & $\sim$ \\
\hline Editorial Advisors & $\sim$ & $\sim$ & $\sim$ \\
\hline Acknowledgements & $\sim$ & $\sim$ & $\sim$ \\
\hline Subscription & $\sim$ & $\sim$ & $\sim$ \\
\hline Advertising & $\sim$ & $\sim$ & $\sim$ \\
\hline Submissions & $\sim$ & $\sim$ & $\sim$ \\
\hline Back Issues & $\sim$ & $\sim$ & $\sim$ \\
\hline Grant Support & $\sim$ & $\sim$ & $\sim$ \\
\hline Dedication & $\sim$ & $\sim$ & $\sim$ \\
\hline Foreword & $\sim$ & $\sim$ & $\sim$ \\
\hline Asemka: Editorial & $\sim$ & $\sim$ & $\sim$ \\
\hline
\end{tabular}

\section{Articles}

First Section - French

Britwum, A. G.

Insuffisances Théoriques Des Damnés De La Terre De

Frantz Fanon

Kodah, M. K.

Disculpation de Dieu dans le malheur des hommes:

Une lecture critique de Gouverneurs de la rosée de Jacques Roumain

Addo-Danquah, $O$.

Le récit de pensées: Une analyse comparative de Vol de nuit d'Antoine de Saint-Exupéry et $\mathbf{L a}$ Condition humaine d'André Malraux

Kodah, M. K. \& Togoh, A. A. X.

Réactions des femmes face au conflit de genre dans C'est le soleil qui m'a brûlée et Tu t'appelleras Tanga de Calixthe Beyala $\sim \quad \sim \quad 45-59$

Kudi, M. D. 
La Littérature francophone face aux médias de télécommunication : Une nouvelle dynamique de la création romanesque, le cas de L'Énigme de retour et Tout bouge autour de moi de Dany Laferrière $\sim$ 60-72 Gli, $M$.

Les faces du bonheur dans Vol de nuit d'Antoine de Saint-Exupéry $\sim \sim$ $\sim 73-85$

Krakue, S. P.

Christ haïtien : Gouverneurs de la rosée et La Bible $\sim 86-93$

Afari, E. S. K. \& Yegblemenawo, C. A. A.

Apports de la télésérie à l'amélioration de la compétence d'expression orale du FLE à l'école normale $94-116$

Bationo, J.-Cl.

Didactique de la littérature et littérature didactique:

l'exemple de la littérature africaine francophone en classe de langues étrangères au Burkina Faso

Second Section - English

Krakue, S. P.

Quod erat demonstrandum: A comparative study of narrative technique in Ama Ata Aidoo's Changes and Albert Camus' Les justes (The Just Ones) 〜 $\sim$ $133-141$

Adjandeh, E. A.

Analysis of Wole Soyinka's Trials of Brother Jero in Relation to Ghanaian Religious Discourse

Sam, C. A.

Decolonizing the Postcolony: Of Men, Spatial Politics and the New Nation in WA Thiongo's Wizard of the Crow.

Kambou, M. K. \& Traore, S. A.

Manipulation and the popular uprising in

Burkina Faso in 2014. $\sim \sim 172-189$ De-Soura, A. Y. M.

Test-taking Strategies of University of Cape Coast Students of 
Kambou, M. K. \& Soma, L.

Local Culture and EFL Vocabulary Learning

Kabore, A. \& Nazortin, C.

Critical Analysis of the Place and Importance of Literature in the Teaching / Learning of English and in School Leaving Certificate Examination in Burkina Faso from 1985 to 2018

Malgoubri, I., Sawadogo, M. \& Kambou, M. K.

Digital Audio-visuals Aids and Listening in English as a

Foreign Language Classrooms

Osei, R. N. \& Inusah, $H$.

A Critique of the Images of Heaven in the Scriptures of the Abrahamic Religions: An Existentialist Perspective

Negedu, A. K.

Lexical Gaps and Ideological Shift in the Translation of

Chinua Achebe's Things Fall Apart as "Le Monde

S'effondre" in French

Talburt, $T$.

Political Transformation and Development in Africa:

Lessons from Achebe's Things Fall Apart 


\section{FORWORD}

All the papers in this Volume were presented at a three-day Conference in honour of Professor Atta Gyamfi Britwum who turns eighty years in March 2021. Most of those years he spent at University of Cape Coast, having cut his teeth as a young lecturer in French language and Literature-in-French in 1974. After many years of an illustrious career in teaching, publication and extension, he bowed out at age seventy, but he didn't get the well-deserved rest he was entitled to; he continues to support his Department and the University as a whole. Today, Professor Britwum's name is associated with high standards of professionalism which earned him the nickname 'L'oracle'. Indeed, it is impossible to find another name universally acknowledged as embodying the excellence in French education offered at the Department of French, University of Cape Coast.

The decision to honour Professor Britwum couldn't have been taken at a more appropriate time. It was planned to coincide with the fiftieth anniversary of the publication of the Beautyful ones are not yet Born, Ayi Kwei Armah's first novel. Britwum never grew tired of reading, teaching and examining it. Such was his respect for Armah's craft. So, the three-day Conference was as much a celebration of Armah's contribution to the shaping of the African novel as it was a tribute to Professor Britwum's work as a teacher of literature of immense influence.

One only has to look at the titles of the papers published in this Volume to get an idea of how deep his influence runs at UCC and beyond. Most of the contributors once upon a time sat at the master's feet, but are now scholars in their own right keeping the flame of French scholarship burning bright (George Cooper: "Polished in a high degree, as each froggie ought to be/Now they sit on other logs, teaching other little frogs.") A good number of the papers are on Literature, nonetheless not limited to Armah's works. No Surprise there. Nevertheless, there are Language papers there too. No surprise here either, for the man to whose honour the Volume is dedicated is equally at home in both Language and Literature

\section{Lawrence K. Owusu-Ansah, \\ Department of English, UCC. \\ A Disciple}


This Special Edition of $A S E M K A$, a bilingual literary journal of the University of Cape Coast, is published in honour of Prof. Atta Gyamfi Britwum, a revered Associate Professor of Francophone African Literature and Civilisation in the Department of French, U.C.C. It contains twenty (20) papers centred on diverse areas of teaching and research in the Humanities and on the theme of the Conference - Literature and the Humanities in the $21^{\text {st }}$ Century: Interdisciplinary Perspectives - held in his honour by the Department of French, University of Cape Coast, Ghana, $13^{\text {th }}-15^{\text {th }}$ Mars, 2019. To reflect Prof. Britwum's area of research interest, the essays are arranged in two sections according to his dominant medium of instruction (French language) and speciality (Literature and Civilisation), followed by those in English language. The first section consists of a set of nine (9) essays in French spanning between themes in Literature and Language. The second section is made up of a set of eleven (11) essays in English which examine issues in literary studies, Language and Didactics, ICT and French Education, Philosophy, and Translation, among others. This special arrangement is however representative of the bilingual nature of the Journal.

\section{First Section}

Britwum, A. G.'s paper titled, “Insuffisances Théoriques Des Damnés De La Terre De Frantz Fanon", presents the Fanonian perspective as a complement to the African nationalism that informed anticolonial struggles. The study posits that African nationalism, populist in nature, for failing to target the capitalist economic base, which defines colonialism, ended up strengthening it. It concludes that Fanon's anticolonialist perspective, despite its overt radicalism, is not designed to allow a "bottom-to-top change" in colonial / capitalist society.

Kodah, M. K.'s paper titled, "Disculpation de Dieu dans le malheur des hommes: Une lecture critique de Gouverneurs de la rosée de Jacques Roumain", puts into question the responsibility of God in the suffering of men on earth and the capacity of man to make and unmake himself. The study aims at absolving God of the guilt of the miseries of men, and also questioning the atheistic or anti-religion denunciation of this narrative 
text since its publication. The study is accomplished through a critical reading and a thoughtful analysis of Jacques Roumain's Gowverneurs de la rosée within the analytical structure of literary studies and sociocriticism.

Addo-Danquah, O.'s paper, "Le récit de pensées: Une analyse comparative de Vol de nuit d'Antoine de Saint-Exupéry et La Condition humaine d'André Malraux", drawing inspirations from theorists such as Léon Edel (1961) and later Dorrit Cohn (1981), examines what Antoine de Saint-Exupéry's Vol de nuit by and André Malraux's La Condition bumaine respectively can offer on the side of representations of the interior life. The study is posited within the framework of narratological theories.

Kodah, M. K. \& Togoh Tchimavor, A. A. in "Réactions des femmes face au conflit de genre dans C'est le soleil qui m'a brûlée et Tu t'appelleras Tanga de Calixthe Beyala" examine the reactions of women to gender conflict in Calixthe Beyala's C'est le soleil qui m'a brulée and Tu t'appelleras Tanga. The study critically reflects on the various ways women in Beyala's C'est le soleil qui m'a brulée and Tu t'appelleras Tanga react to oppression and exploitation resulting from patriarchal domination. It therefore examines the sources and nature of this conflict, and how women react to it in the two novels. The study points to the fact that, much as conflict emanating from patriarchal oppression and male's domination in human societies is inimical to the rights of women, the methods used by the latter to free themselves from this state of being remain questionable, in that, these methods defy rational thinking and are also a kind of reversal oppression and domination which are equally unacceptable.

Kudi, M. D.'s paper, “La Littérature francophone face aux médias de télécommunication: Une nouvelle dynamique de la création romanesque, le cas de L'Énigme de retour et Tout bouge autour de moi de Dany Laferrière", seeks to examine how pertinent painting, photography, television, telephone etc. are to the production of the contemporary Francophone novel. The study focuses on L'Énigme de retour (2009) and Tout bouge autour de moi (2011). The analysis is based on the perspective of literary intermediality propounded by Jürgen E. Muller which is characterised by an interaction between telecommunication media and literary text. The study establishes through these selected novels that these media forms are not simply another form of expression in the novel but rather a lens through which the story is narrated. 
Gli, M.'s paper titled, "Les faces du bonheur dans Vol de nuit d'Antoine de Saint-Exupéry", analyses the faces of happiness in Antoine de Saint-Exupéry's Vol de Nuit. The study is conducted through thematic approach. This approach is complemented by Maslow's theory of human needs. The collection of data or the collection of information is purely documentary. The study therefore seeks to establish a link between individual happiness and collective happiness in Saint-Exupéry's selected narrative text.

Krakue, S. P.'s paper, “Christ haïtien : Gouverneurs de la rosée et La Bible", attempts to question Jacques Roumain's Gouverneurs de la rosée in order to elucidate the novelist's use of the biblical text in his creative activity. The study demonstrates that Jacques Roumain's narrative text turns out to borrow biblical ideas not only to develop his plot but also to design his main character.

Afari, E. S. K. \& Yegblemenawo, C. A. A. in “Apports de la télésérie à l'amélioration de la compétence d'expression orale du FLE à l'école normale." examine the impact examine the impact of the use of serial movies as teaching aid on oral expression of French language learners in Colleges of Education in Ghana with the aid of smartphones. The study discovers that the use of serial movies in teaching French boosts learners' performance in oral communication. It therefore recommends that serial movies could be used in teaching French language lessons in order to enhance the oral communication competencies among learners.

Bationo, J.-Cl.'s paper titled, "Didactique de la littérature et littérature didactique : l'exemple de la littérature africaine francophone en classe de langues étrangères au Burkina Faso", shows not only how to teach literature in language class but also how to use didactic literature to develop social skills among learners to reduce vandalism, school violence, negative stereotypes, misunderstandings of intercultural nature while cultivating social peace and living together in a context of internationalization, globalization and digital revolution. The paper focuses on francophone African Literature and posits that methodological approach used for the didactic transpositions of literary content is based on the new orientation and the redefinition of the objectives of language teaching and on the didactic models of the aesthetic reception of didactics of literature which requires putting the learner in intensive interaction with the text and motivating $\mathrm{him} /$ her to express himself/herself on his/her reading experiences. 


\section{SECOND SECTION - ENGLISH}

Krakue, S. P.'s paper titled, “Quod erat demonstrandum: A comparative study of narrative technique in Ama Ata Aidoo's Changes and Albert Camus' Les justes (The Just Ones)", demonstrates through textual analysis, how in Ama Ata Aidoo's Changes and Albert Camus Les justes, the authors resort to a specific form of irony to bring the discussion of issues raised to a conclusion. The technique consists in demonstrating clearly a huge discrepancy between a "fine" idea and its practical usefulness. Both authors successfully use narrative technique. Albert Camus demonstrates the hollowness of the idea of fighting for justice through revolutionary violence and Ama Ata Aidoo similarly demonstrates the fatuousness of the theory of women-emancipation-through-polygamy.

Adjandeh, E. A. analyses selected reports in Ghanaian media in relation to the clergy and identifies how Wole Soyinka's theme is reflected in these media in her paper titled, "Analysis of Wole Soyinka's Trials of Brother Jero in Relation to Ghanaian Religious Discourse". The study seeks to examine the extent to which themes in Soyinka's Trials of brother Jero play out in religious discourses in Ghana. The global nature of the issues problematized by Wole Soyinka also comes out through this study as the work set in Nigeria is analyzed in relation to the selected articles set in Ghana. The paper relies on a content analysis of Trials of Brother Jero and similar themes presented in the selected articles, and makes a few recommendations on how these religious issues could be partially, if not wholly, resolved in Ghana.

Sam, C. A.'s paper, "Decolonizing the Postcolony: Of Men, Spatial Politics and the New Nation in WA Thiongo's Wizard of the Crow", examines how Ngugi Wa Thiongo's Wizard of the Crow blatantly explores Africa's complicity in a seemingly cyclic colonization in the $21^{\text {st }}$ century and its attendant consequences for the total liberation of Postcolonial Africa. The study examines the correlation between masculine representations, spatial reorganization and futurity as alternative ways in thinking about Africa's future through Bakhtin's theory of the carnival and other such concepts as polyphony and the grotesque. The result of the analysis is that the correlation between forms of communities and forms of masculinities is an indication of a vision of hope for Postcolonial Africa. 
Kambou, M. K. \& Traore, S. A. in "Manipulation and the popular uprising in Burkina Faso in 2014", analyse the different discourses in the build-up to the popular uprising in Burkina Faso on the $30^{\text {th }}$ and $31^{\text {st }}$ October 2014. It attempts to clarify how political and civil society leaders use language and other non-linguistic elements to influence the ordinary citizens' minds and, indirectly, their actions. The analysis is premised on Van Dijk's (2006) Sociocognitive approach. The paper analyses the cognitive, the social and the discursive dimensions of manipulation in six political speeches (two speeches from Civil Society, two from the ruling party and two from the political opposition). The results suggest that the three groups manipulated their audiences, and finally, the ruling party lost following the resignation of the then Head of State, making way for a Transition government to take over the reins of governance.

De-Souza, A. Y. M.'s paper "Test-taking Strategies of University of Cape Coast Students of French as a Foreign Language: a Case Study." seeks to provide a description of test-taking strategies that may inform teaching and learning of French for better output in tests against the background that Ghanaian students of French as a foreign language deploy strategies that are not adequate enough in answering test items in French. The study examines data gathered right after a French test by level 200 students, using recollective verbalization protocols.

Kambou, M. K. \& Soma, L. examine in their paper titled, "Local Culture and EFL Vocabulary Learning", the influence of learners' culture on foreign language vocabulary. The paper seeks to demonstrate that there is a link between culture and lexico-semantic errors committed by learners of English as a foreign language among Dioula speaking students in Burkina Faso. A language test composed of two written activities was used as the data collection instrument. The results revealed that the Dioula speakers' English is influenced by their culture. These results have some pedagogical implications. They, therefore, suggest that we adapt the teaching of EFL vocabulary to learners' culture.

Kabore, A. \& Nazortin, C. in "Critical Analysis of the Place and Importance of Literature in the Teaching / Learning of English and in School Leaving Certificate Examination in Burkina Faso from 1985 to 2018", analyse the types of texts given at the "Baccalaureate A" written examination in the last thirty years. In this study, quantitative and qualitative 
data are collected. Baccalaureate written English papers are the main focus of our collection. Teachers and supervisors are interviewed. The study is grounded on "Reader-Response Theory" which stresses the interactions between the reader and the text. The results of the study show that the great majority of texts proposed for "Baccalaureate A" examination, in the last thirty years, are non-literary texts.

Malgoubri, I., Sawadogo, M. \& Kambou, M. K.'s paper titled, “Digital Audio-visuals Aids and Listening in English as a Foreign Language Classrooms", is an experimental study which investigates the potential of digital audio-visuals to improve the listening skills of EFL learners in secondary schools in Burkina Faso. On the assumption that learners born around the year 2000 are digital natives, the researchers try integrating smartphone-friendly audio-visuals in their EFL classrooms in a four-week experiment involving one Experimental Group and one Control Group. The experiment aims at gauging the effectiveness of those aids operated via students' smartphones in improving learners' listening and speaking skills. Independent T-tests were used to compare the groups and Sample Paired TTests to make comparisons within groups. The study suggests that, if appropriately used, smartphones are excellent devices for language teachers and learners in this digitizing world.

Osei, R. N. \& Inusah, H.'s paper, “A Critique of the Images of Heaven in the Scriptures of the Abrahamic Religions: An Existentialist Perspective." Critically examines the scriptural images of heaven as captured in the Abrahamic religions - Judaism, Christianity and Islam - from the existentialist perspective. The paper argues that the idea of life beyond this earthly existence for all human beings in a specially prepared location by God for eternal happiness for those who obey His commands on earth called Heaven, as propounded by the Abrahamic Religions, throws up a lot of problems, especially from the existentialist perspective. The study concludes that the scriptures' constructs of heaven appear self-contradictory and fail to strike a chord with the contemporary image of the ideal society when perused from the existentialist perspective and should, therefore, be discarded.

Negedu, A. K.'s paper "Lexical Gaps and Ideological Shift in the Translation of Chinua Achebe's Things Fall Apart as "Le Monde S'effondre"in French." examines the ideological divergence between the title of the original text and the title of the translation, following an observation 
that in translating Chinua Achebe's Things Fall Apart, Michel Ligny translates directly Igbo terminologies, realities and beliefs into the French language. The paper concludes that the ideology that the translated title projects to French-readers is totally different from the ideology that the original title projects to English-readers.

Talburt, T., in "Political Transformation and Development in Africa: Lessons from Achebe's Things Fall Apart", formulates critical perspectives on the significance of Achebe's novel for the socio-political and economic transformation and development of the African continent. The paper challenges one of the central assumptions in this story that Africa falls apart as soon as it comes in contact with Europe. It questions aspects of political conservatism exhibited in Okonkwo who is suspicious of fundamental changes to his society. The discussion is based on the jollof rice principle of political hybridisation of development which proposes the amalgamation of Westernised and non-Western ideas and systems, in order to achieve economic development, rather than totally rejecting Westernisation in its entirety. The study uses examples of Western-style democracy and State intervention in Africa to demonstrate the significance of embracing some aspects of Westernisation through political hybridisation. 




\title{
Le récit de pensées : Une analyse comparative de Vol de nuit d'Antoine de Saint-Exupéry et La Condition humaine d'André Malraux
}

\author{
O. Addo-Danquah \\ University of Cape Coast, Cape Coast, Ghana.
}

\begin{abstract}
Souvent, une analyse du texte narratif se concentre sur les aspects des paroles des personnages, de la description et de la narration des épisodes et événements perçus de l'extérieur. Or, l'on sait à partir des travaux des théoriciens des textes narratifs des analyses psychologiques depuis des siècles que la vie intérieure des personnages compte beaucoup plus que l'espace qui lui est accordée. Désormais, les textes narratifs seront mieux appréciés si les récits sont abordés en tenant compte des possibilités différentes mais fascinantes qu'ils offrent pour les études littéraires. C'est ce que démontrent les travaux des théoriciens tels que Léon Edel (1961) et plus tard Dorrit Cohn (1981) dont nous nous inspirons pour cette étude. Notre attention s'arrête sur deux romans de la littérature française, Vol de nuit d'Antoine de Saint-Exupéry et La Condition bumaine d'André Malraux respectivement. Classés, l'un comme l'autre parmi les romans d'aventures, ces deux textes peuvent également être recensés dans les rangs des romans d'action étant donné qu'ils représentent des aventures de différents domaines. De la sorte, l'on s'attendra à voir les deux romans composés à profusion d'épisodes et d'événements. Toutefois, cela n'est pas le cas comme ils regorgent chacun, une quantité conséquente de récits de l'univers intérieur. D'où l'intérêt grandissant d'examiner ce qu'ils peuvent offrir du côté des représentations de la vie intérieure. En nous inspirant des théories narratologiques, nous comptons prêter le schéma proposé pour mener à bien cette prochaine étude des deux textes narratifs.
\end{abstract}

Mots-clés: analyse ; événement ; intérieur ; parole ; pensée ; récit. 


\section{Introduction}

Notre propos, dans la présente étude est d'analyser, d'une manière comparative les récits de pensées dans deux romans français du 20 e siècle à savoir, Vol de nuit d'Antoine de Saint-Exupéry et La Condition bumaine d'André Malraux respectivement. Nous allons nous pencher sur l'apport de cet aspect de la technique littéraire à l'étude des deux textes, appartenant au classement des textes classiques de la littérature française.

Classés, l'un comme l'autre dans la catégorie des romans d'action, Vol de nuit et $\mathrm{La}$ Condition bumaine recèlent des quantités assez conséquentes de représentations d'activités de la vie intérieure des instances qui méritent d'être étudiées à fond tant qu'elles donnent des perspectives profondes pour mieux apprécier les deux textes. C'est en ceci, pour ainsi dire que réside la motivation qui sous-tend cette présente étude.

Vol de nuit, comme La Condition humaine se portent sur des problèmes de la quête du sens de l'existence humaine. D'une part, le premier, se basant sur une prétendue aventure d'aviation, essaye de découvrir le sens du devoir en cherchant à asseoir le principe de vol de nuit. Se faisant, la narration part des exploits des pilotes engagés dans l'aventure pour poser cette question : qu'estce qui donne un sens à la vie ? Raymond Queneau (éd) (1958) fait la part belle des choses lorsqu'il précise en dévoilant la préoccupation de l'auteur que "Saint-Exupéry ne débat (dans ce texte) qu'un problème: comment vivre, selon les valeurs de l'action, du courage, du risque, du combat, sans détruire ce qui est leur justification : la vie humaine ?».

A cette interrogation, Queneau en propose lui-même la réponse dans les termes suivants : «En se sacrifiant pour autrui, en créant l'œuvre d'art, en hasardant l'existence personnelle au sacrifice de la communauté ». (p. 1350). Bref, l'existence de l'être humain doit être entièrement dédiée au service des autres sans en compter le coût. C'est ce que la narration et la représentation, à travers les pages du texte, peinent à démontrer en partant du prétexte d'une aventure d'aviation pour établir, finalement les principes du vol nocturne ; et par extrapolation, le principe de l'acceptation du devoir.

D'autre part, le second, s'adressant aux problèmes existentiels tels que l'angoisse, la solitude, et la mort, s'assigne comme préoccupation majeure, le destin de l'homme. Selon Queneau, l'auteur de ce texte se fixe l'objectif de «Tenter de donner conscience à des hommes de la grandeur qu'ils ignorent en eux » Se faisant, poursuit-il, Malraux « cherche à saisir en l'homme le lieu de sa résistance en appelant aux forces capables de transformer un destin subi à un destin dominé » Alors de l'homme, il ne retient que "ce pouvoir d'être supérieur aux fatalités qui le menacent, ce pouvoir susceptible de changer le sens de la souffrance, de la solitude, ou de la mort. » (p. 1352). 
Le roman relate le parcours d'un groupe de jeunes révolutionnaires qui préparent un soulèvement de la ville de Shanghai en Chine en vue de libérer des ouvriers exploités par le capitalisme occidental en place en Chine à l'époque Les révolutionnaires s'assignent le véritable défi de renverser le pouvoir en place pour le remplacer par le communisme ; un système qu'ils estiment être le mieux placé pour assurer une société juste et équitable.

Mener une étude du genre dans laquelle nous nous engageons, nous impose d'emblée un certain nombre de soucis permettant d'orienter, carrément, les analyses et dont nous pouvons souligner quelques-uns. Nous allons essayer, dans un premier temps de déterminer sous quelles formes les récits de pensées se manifestent dans chacun des romans. Nous allons, ensuite déterminer les formes dominantes dans chacune des textes et voir, finalement, comment elles aident à donner une meilleure appréciation à la narration.

\section{Cadre théorique et état de lieu des travaux précédents}

Notre analyse se fonde sur les théories des techniques du récit; plus spécifiquement, celle de la représentation des activités intérieures dans les textes narratifs. Nous pouvons ainsi partir des théories amorcées par des travaux des structuralistes comme Barthes (1966), Todorov (1966, 1973), Jakobson $(1973,2017)$ puis continuées, dans la tradition française aussi bien qu'anglaise par d'autres théoriciens comme Humphrey (1972), Weismann (1979) et Dujardin (2008). Nous ne pouvons pas nous passer, non plus des travaux continués et élargis dans le domaine surtout par Genette $(1972,1983)$, et repris tardivement par Angelet \& Herman (1993) pour terminer, enfin, avec ceux de Chardin (2004) et de Rabatel (1997, 1998, 2008).

Toutefois, nous ne pouvons pas laisser de côté les études de Cohn (1981) à l'instar des analyses de la mode de la représentation de Genette et qui, à notre estime élabore la théorie la plus intégrale pour des analyses des activités de la vie intérieure dans le domaine des études littéraires. Cohn distingue trois techniques par le biais desquelles l'on saisit la technique du récit de pensées.

D'abord, l'on a le psycho-récit que Cohn définit comme «le discours du narrateur sur la vie intérieure d'un personnage ». Puis, il y a le monologue rapporté qui représente «le discours mental d'un personnage cité tel quel ». Finalement, il y a le monologue narrativisé, "le discours mental d'un personnage pris en charge par le discours du narrateur ». Pour mieux éclairer les trois techniques de Cohn, voyons comment le même énoncé peut se transformer à travers les trois formes différentes de la technique :

- Psycho-récit: Il pensait avec angoisse qu'il ne serait pas à l'heure, qu'elle partirait sûrement. 
- Monologue rapporté : Il se disait «Je ne serai pas à l'heure, elle partira sûrement »

- Monologue narrativisé : Il ne serait pas à l'heure, elle partirait sûrement.

Il est pertinent de noter les transformations structurales que subit l'énoncé original engendrées par des changements grammaticaux pour permettre de saisir assez lucidement ce que nous voulons faire comprendre. L'on part de la proposition subordonnée à l'imparfait pour rejoindre la proposition principale dans laquelle les deux verbes (serait et partirait) sont au conditionnel présent. Dans le monologue rapporté, le verbe de la subordonnée reste inchangé alors que ceux de la principale, se transforment au futur. Au monologue narrativisé, la subordonnée disparait au profit d'une construction où le discours indirect libre domine et les verbes restent toujours au conditionnel présent. Notons également, les signes de la ponctuation qui démarquent les propositions.

Notre étude s'inspire des travaux identiques réalisés précédemment dans le domaine du récit de pensées traitant des aspects des activités de l'univers intérieurs des actants. Nous pouvons d'emblée, évoquer les études de Philips (1994), d'Addo-Danquah (2002,2012), et de Garnier (2004) qui, de différentes perspectives, explorent des activités intimes des personnages dans les récits respectifs dans le but ultime de livrer aux lecteurs ce que les personnages conçoivent au fin fond d'eux-mêmes tout en préférant se les cacher.

\section{Analyses des récits de pensées dans Vol de nuit et La Condition humaine}

\section{Les psycho-récits dans Vol de nuit et La Condition humaine}

Au départ de la narration dans $V o l$ de nuit, l'on assiste aux flux de conscience de Fabien, l'un des pilotes de la compagnie aérienne chargé de l'avion revenant de la mission en Patagonie. En survolant des habitations humaines, Fabien qui contemple les mouvements des êtres vivants en bas, se considère comme un berger mis en charge de toutes ces créatures devenues insignifiantes par la distance qui les sépare. Le narrateur omniscient, qui l'accompagne en ce voyage représente ce qui traverse l'esprit du pilote qu'il fait par ainsi aux lecteurs :

Il eût pu croire aussi, dans ce calme, faire une lente promenade, presque comme un berger. Les bergers de Patagonie vont, sans 
se presser, d'un troupeau à l'autre : il allait d'une ville à l'autre, il était le berger des petites villes. Toutes les deux heures, il en rencontrait qui venaient boire au bord des fleuves ou qui broutaient leur plaine. (p. 20)

Alors que le pilote se régale dans ses réflexions de son nouveau rôle de berger qu'il vient de s'assigner, son radio contemple les dangers imminents qu'annonce le temps qu'il fait ce que le narrateur relate ainsi aux lecteurs : «Mais le radio pensait que des orages s'étaient installés quelque part, comme des vers s'installent dans un fruit; la nuit serait belle et pourtant gâtée : il lui répugnait d'entrer dans cette ombre prête à pourrir. » (p. 21).

Le lecteur saisit l'appréhension du radio qui émane de son inquiétude mais qu'il ne verbalise pas. Pourtant, grâce à la présence des verbes de perception tels que " penser », le lecteur saisit cet état d'âme du personnage.

Ailleurs dans La Condition bumaine l'on suit les contemplations de Tchen, un des terroristes révolutionnaires qui ; devant la tâche qu'il doit accomplir à l'égard de la révolution, se trouve complètement sidéré par l'énormité de l'action. Le narrateur, grâce à son omniscience fait part de ce qui traverse l'âme du personnage en ce propos : «Il se répétait que cet homme devait mourir. Bêtement : car il savait qu'il le tuerait. Pris ou non, exécuté ou non, peu importe ». (pp. 9-10).

L'emploi des verbes à l'imparfait -(« se répétait », « devait», "savait», « importait»)- donnerait lieu à croire -à tort, bien sûr- qu'on est déjà dans le domaine du monologue narrativisé mais, la présence des pronoms de subordination; " que » fait voir d'emblée que l'on suit des représentations par le biais du psycho-récit. Opérant dans cette optique, le narrateur continue de faire part de l'état d'âme de Tchen qu'il relate ainsi :

Les paupières battantes, Tchen découvrait en lui jusqu'à la nausée, non le combattant qu'il attendait, mais un sacrificateur. Et pas seulement aux dieux qu'il avait choisis: sous son sacrifice à la révolution grouillait un monde de profondeurs auprès de quoi cette nuit écrasée d'angoisse n'était que clarté. (p. 10).

L'on peut observer ici l'absence du pronom de la subordination «que » par lequel l'on arrive, en partie, à déterminer les énoncés en psycho-récit. Toutefois, il est possible, grâce à l'expression « en lui » de situer correctement le foyer de la représentation au fin fond du personnage. Demeurant dans cette dimension, le narrateur continue à relater les intimités des personnages lorsqu'il continue à faire part des sentiments de Rivière qui, en réfléchissant sur 
ses énormes responsabilités de chef d'entreprise, se plaint de sa misère qui est relaté ainsi par le narrateur : «Il est dur, pensait-il, d'être un juge. » (p. 45).

Et ce dernier, de continuer à relever les sentiments traduisant l'intimité de Rivière, représente encore aux lecteurs ce que celui-ci se dit en guise de justification de sa sévérité envers ses employés: "Rivière pensa qu'ainsi, chaque nuit, une action se nouait dans le ciel comme un drame. Un fléchissement des volontés pouvait entraîner une défaite, on aurait peut-être à lutter beaucoup d'ici le jour. » (p. 62). On dirait qu 'à force d'assumer, presque seul, l'énorme responsabilité de conduire à bon port les opérations de la compagnie d'aviation, Rivière est réduit à un perpétuel rêveur qui contemple toujours le devenir de l'entreprise. En comparant sa vie de misanthrope à celle des gens heureux qui semblent en jouir pleinement, Rivière éprouve le chagrin de ne pas mener une vie normale comme d'autres personnes. Toutefois en pesant bien l'argument, il se console du fait que tout ne peut pas être aussi morne qu'il s'imagine ; son train de vie, après tout compte pour quelque chosece qui le fait épouser l'opinion suivante sur la vie en générale :

Il pensa qu'autour de leur kiosque à musique les petits bourgeois des petites villes vivaient une vie d'apparence silencieuse, mais quelquefois lourde aussi de drames:la maladie, l'amour, les deuils, et peut-être...Son propre mal lui enseignait beaucoup de choses: " Cela ouvre certaines fenêtres », pensait-il. (p. 71).

À travers de telles indications comme des flux de conscience, des écoulements intérieurs et des émotions des personnages, l'on arrive à décortiquer les énoncés en psycho-récit qui aident à trier correctement les énoncés pour mieux les analyser.

\section{Les monologues rapportés dans Vol de nuit et La Condition humaine}

Passons maintenant aux extraits recueillis des deux textes pour montrer l'emploi du monologue rapporté dans la représentation. Il serait bien de tirer l'attention sur la présence des signes de ponctuation qui démarquent nettement les énoncés annonciateurs du narrateur de ceux des provenant des personnages. De la sorte, l'on part du principe de la subordination dans les énoncés illustrant le psycho-récit pour retrouver celui où les marques de la ponctuation définissent les énoncés en monologue rapporté. Considérons, à titre d'exemple les illustrations suivantes qui aident à clarifier ce que nous voulons faire comprendre. 
Occupé toujours par des réflexions à propos de son attitude envers ses employés, attitude qui donne de lui l'image erronée d'un dictateur de la pire espèce, Rivière ne peut plus retenir ce qu'il ressent en lui et, comme pour se justifier, se demande silencieusement :

«Suis-je juste ou injuste ? Je l'ignore. Si je frappe, les pannes diminuent. Le responsable, ce n'est pas l'homme, c'est comme une puissance obscure que l'on ne touche jamais, si l'on ne touche pas tout le monde. Si j'étais très juste, un vol de nuit serait chaque fois une chance de mort. » (pp. 80-81).

Visiblement humain comme tout, Rivière ne peut à jamais rester inconscient de l'opinion des autres concernant son attitude, peut-on le dire intraitable envers ses subalternes. Cherchant à apaiser son esprit évidemment troublé, Rivière, pour se justifier, pense à son comportement quelque peu contradictoire que le narrateur omniprésent, n’hésite aucunement à relayer de la manière suivante aux lecteurs : Rivière pensa : «Ce n'est pas lui que j'ai congédié ainsi, brutalement, c'est le mal dont il n'était pas responsable, peutêtre, mais qui passait par lui ». (p. 83).

Inversement, dans La Condition bumaine, l'on assiste toujours aux hésitations de Tchen qui, apparemment sidéré devant l'acte meurtrier qu'il doit accomplir au nom de la révolution, en pèse la gravité : «Quatre ou cinq klaxons grincèrent à la fois. Découvert ? Combattre, combattre des ennemis qui se défendent, des ennemis éveillés. » (p. 9).

Et cherchant à se justifier de l'acte imminent du meurtre devant lequel il se trouve immobilisé, il tient en lui ce discours dont le narrateur, omniprésent, en fait part aux lecteurs : "Assassiner n'est pas seulement tuer...». (p. 10). Toutefois, l'on sait que commettre un meurtre constitue un crime qui ne se justifie aucunement. Ostensiblement étonné, lui-même, de son incapacité à accomplir la tâche, Tchen se doutant maintenant de sa bravoure, se pose naturellement cette question: «Est-ce que je deviens imbécile? ». (p. 10).

Ces deux énoncés, comme l'on peut le voir, sont des représentations des émotions qui traduisent le for intérieur de Tchen, le personnage, à qui le courage fait à présent défaut pour lui permettre de verbaliser lucidement ce qu'il ressent en lui, de peur, bien sûr, d'être surpris, voire même, d'être appréhendé par les forces de l'ordre.

Ailleurs dans Vol de nuit, l'on assiste aux inquiétudes de Rivière, chef emblématique de l'entreprise d'aviation qui assure seul, avec grande fortitude son calvaire d'asseoir, dans une société largement incrédule et réticente, son principe de vol de nuit. Se questionnant pour apaiser en quelque sorte, son 
esprit agité, quant aux méthodes de contrôle pour régler le comportement des employés, Rivière, comme en train de s'évaluer, donne libre cours à ses sentiments que le narrateur représente ainsi: "Il pensa encore pour se rassurer : «Tous ces hommes, je les aime, mais ce n'est pas eux que je combats. C’est ce qui se passe par eux...». (p. 86).

On le saisit, un peu plus tard dans ses rêveries d'auto-évaluation lorsqu'il s'assure de la justesse de son comportement en se disant :

Je ne sais pas si ce que j'ai fait est bon. Je ne sais pas l'exacte valeur de la vie humaine, ni de la justice, ni du chagrin. Je ne sais pas exactement ce que vaut la joie d'un homme. Ni une main qui tremble. Ni la pitié, ni la douleur... . (p. 86).

Et Rivière de conclure ses réflexions à propos de ses aveux en remarquant que : «La vie se contredit tant, on se débrouille comme on peut avec la vie...Mais durer, mais créer, échanger son corps périssable... ». (p. 86).

Ainsi, pour Rivière, ce qui valorise l'existence d'un être humain et qui prime dans ce monde, c'est d'œuvrer toute sa vie, presque sans repos, au profit du progrès de la société. Il s`est acquis à l'idée de faire asseoir le principe de vol de nuit qu'il estime pouvoir apporter un énorme avancement globale dans l'entreprise de l'aviation. Sa pensée, quant à la nécessité d'œuvrer perpétuellement pour le progrès de l'humanité, abonde apparemment dans le même sens que Frederick Buechner (1973 : 28) lorsqu'il affirme que : «Only a life given away for love's sake is a life worth living ». Rivière s'est donné entièrement pour apporter un remarquable progrès dans l'entreprise de l'exploitation de l'aviation avec le but ultime de hausser la qualité de la vie humaine dans le secteur du transport.

C'est le même chemin que poursuivent les révolutionnaires communistes dans La condition bumaine, ou le narrateur continue à relever aux lecteurs les écoulements des personnages lorsqu'il capte Tchen, en train d'être contrôlé par les agents de la police, se rassurer dans ces termes : «Ce que je viens de faire ne se voit décidément pas ». (p. 16). Plus tard, Tchen va retrouver le vieux Gisors, l'un des anciens patrons des terroristes, pour lui faire part des inquiétudes qui traversent son esprit à la suite du meurtre qu'il a commis.

Contemplant la vie de Tchen dès son enfance, le vieux Gisors, dans ses pensées, pèse le caractère de son interlocuteur établissant, ainsi de probables similitudes avec le caractère de son propre fils, Kyo. Le narrateur qui suit de près les propos du vieux, les relate ainsi au lecteur : "Je pense à son esprit religieux parce que Kyo n'en a jamais eu, et qu'en ce moment toute 
différence profonde entre eux me délivre...Pourquoi ai-je l'impression de le connaitre mieux que mon fils ?» (pp. 66-67).

Encore pris dans ses propres réflexions, le vieux Gisors s'empresse d'ajouter aussitôt: "Mais si je le savais vraiment, et pas de cette façon incertaine et épouvantable, je le sauverais. » (p. 69).

En pensant plus tard à l'état d'un prisonnier qu'il vient tout à l'heure de sauver, Tchen se débat avec sa conscience à propos du bien-fondé de son action : «Je n'avais qu'à laisser ce type. Pourquoi être allé couper ses cordes, ce qui ne pouvait rien changer ?». (p. 100). Clairement, Tchen fait noter en partie, quelques-unes des frustrations des révolutionnaires qui se jugent peu appréciés par les mêmes gens dans l'intérêt desquels ils se sont sacrifiés.

\section{Les monologues narrativisés dans Vol de nuit et La Condition humaine}

Examinons, pour terminer nos analyses, certains énoncés en monologue narrativisé recensés dans les deux textes. Le monologue narrativisé, comme nous l'avons déjà précisé est le discours interne du personnage pris en charge par le narrateur. Rappelons qu'à la différence des deux techniques précédentes, le monologue narrativisé n'a pas de signes visibles qui le démarquent; pas d'indication de subordination, ni de signes de ponctuation pour le délimiter. L'on se trouve donc en présence de la composition du narrateur mais l'idée qui sous-tend la construction appartient au personnage. Considérons des extraits en monologue narrativisé tirés des deux textes.

Comme toujours obsédé par la nécessité de se justifier de son attitude de chef d'entreprise tenace, Rivière, se noie plus souvent dans ses réflexions sur la bonne manière de diriger son équipe d'employés. Le narrateur le surprend dans un de ses moments de réflexions lorsqu'il nous relate ce qui le préoccupe ainsi : «Le message de cette musique venait à lui, a lui seul parmi les médiocres, avec la douceur d'un secret. Ainsi le signe de l'étoile. On lui parlait, par-dessous tant d'épaules, un langage qu'il entendait seul. » (p. 76).

En observant de près la forme que prend l'énoncé, nous pouvons bien noter que les verbes des propositions sont au conditionnel présent et qu'il n'y a ni signes de ponctuation annonciateurs des énoncés, ni de subordination dans les propositions. Par contre, la plupart des propositions sont sous forme de discours indirecte libre. C'est ce qui se révèle, par exemple dans l'extrait suivant où, dans l'expectatif de retour réussi des avions en mission, Rivière contemple la lutte des pilotes pour des atterrissages réussis en se disant en lui :

Les événements, dans le Sud donnait tort à Rivière, seul défenseur des vols de nuit. Ses adversaires tireraient d'un 
désastre en Patagonie une position morale si forte, que peutêtre la foi de Rivière resterait désormais impuissante ; car la foi de Rivière n'était pas ébranlée : une fissure dans son œuvre avait permis le drame, mais le drame montrait la fissure, il ne pouvait rien d'autre. (pp. 112-113).

Malgré cet échec apparent, Rivière trouve des raisons pour persister dans ses exploits périlleux. Il avance des justifications comme pour se consoler lorsqu'il conclut, à propos du désastre imminent que le narrateur représente ainsi aux lecteurs : «S'il avait suspendu un seul départ, la cause des vols de nuit était perdue. » (p. 169).

Dans La Condition humaine, le lecteur éveillé ne peut pas tenir compte des énoncés d'ouverture de la narration où, comme hébété et complètement immobilisé devant l'acte qu'il doit accomplir, Tchen, le terroriste, se débat quant au moyen le plus sûr de tuer l'homme que le narrateur représente ainsi : " Tchen tenterait-il de lever la moustiquaire ? Frapperait-il au travers ? (p. 9).

Face à ce dilemme, Tchen réfléchissant toujours aux conséquences d'un probable échec de son attentat, ne cesse pas de peser sa fortune. Dans l'incertitude, il s'exprime silencieusement en monologue que le narrateur rapporte de la manière suivante :

Un seul geste et l'homme serait mort. Le tuer n'était rien: c'était le toucher qui était impossible. Et il fallait frapper avec précision. (...) Il savait combien il est difficile de frapper de haut en bas. (...) Il eût dû frapper à longueur de bras, d'un mouvement courbe comme celui de swing. (p. 11).

Clairement, c'est la voix du narrateur qu'on entend mais il est aussi évident que ce qu'il verbalise provient, presqu'entièrement de la perspective du personnage incapable d'agir. Ce sont, pour ainsi dire les émois de ce dernier que le premier s'est chargé de rapporter. Tchen se trouve dans une situation vraiment glissante et préfèrera, naturellement, garder le silence de peur d'être surpris. Toutefois, vu l'importance de ce qui traverse son esprit en ce moment, le narrateur omniscient et omniprésent décide d'en faire part aux lecteurs. Cela, certainement aidera à mieux saisir la signification du texte et approfondir sa réception.

L'aventure dangereuse des révolutionnaires dans le texte, fait de $\mathrm{La}$ condition bumaine un roman dans lequel les paroles sont rares. Tout, en effet, s'exécute d'une manière strictement clandestine. Les actions peuvent être facilement perçues mais le raisonnement de leurs exécutions ne sera presque ou pas du tout connu. Souvent, c'est à travers ce que l'on peut saisir dès 
l'intimité des personnages que l'on comprend mieux des faits dans la narration. Vraiment, en réalité, les gens peuvent facilement dissimuler les vrais états de choses depuis l'extérieur. A peine peuvent-ils, avec un degré de réussite conséquente, cacher leurs véritables émotions et intentions.

Dans une de ses tentatives de tuer Chang-Kai- Shek, Tchen entre dans la boutique d'un antiquaire où il espère pouvoir se cacher pour planifier son attentat. Se méfiant du commerçant, Tchen cherche à déterminer la vraie identité de son interlocuteur que le narrateur relate ainsi aux lecteurs :

Ce n'était pas un Shanghaien, mais un Chinois du Nord ou du Turkestan: ses moustaches et sa barbe rares mais floues, ses yeux bridés était un musulman de basse classe, et aussi sa bouche obséquieuse; mais non son visage sans arêtes, de bouc a nez plat. Celui qui dénoncerait un homme sur le passage du général avec une bombe recevrait une grosse somme d'argent et beaucoup de considération parmi les siens. Et ce bourgeois riche était peut-être un partisan de Chang-Kai-Shek. (p. 170).

Comme si les deux sont engagés dans un jeu de qui pro quo, le commerçant, à son tour, fait découvrir ce qu'il s'imagine de la vraie identité de Tchen que le narrateur relate comme suit :

Que pouvait être ce singulier client? (...) Ce jeune homme n'avait peut-être pas l'habitude de porter des habits européens. (...). Le fils de quelque riche paysan de l'intérieur? Mais les gros fermiers ne collectionnaient pas les bronzes anciens. Achetait-il pour un européen ? Ce n'était pas un boy, ni un courrier-et, s'il était amateur, il regardait l'objet qu'on lui montrait avec bien peu d'amour: il semblait qu'il songeait à autre chose. (p. 170).

Le lecteur éveillé ne peut feindre ignorance de l'importance de cette scène qui permet d'emblée de prendre compte de l'atmosphère de méfiance et de soupçon qui perdure dans la société. C'est, heureusement grâce à la source des réalisations des énonces- dans le for intérieur des personnages, que cela reste toujours de la rêverie.

Essayer ainsi de saisir les personnages depuis la profondeur de leurs intimités, s'avère très utile à un saisi presque total de la signification des œuvres. Les récits de pensées, peut-on le conclure, permettent une étude de la mode de narration, vraiment intégrante des textes littéraires. 


\section{Conclusion}

Ce qui ressort des exemples recueillis composant le corpus des analyses ce que la représentation dans $V$ ol de nuit fait usage abondamment du psychorécit et de monologue rapporté au détriment de monologue narrativisé pour faire part des activités du foyer intérieur des personnages. Ce qui reviendrait à conclure que les personnages, réticents pour la plupart, sont bien en charge de leurs propres émotions, sensations et pensées dans la profondeur de leurs esprits.

Inversement, dans La Condition bumaine, la représentation, quant à elle, se répand globalement sur les trois techniques de la révélation des activités intérieures mais à dominante monologue narrativisé. On dirait que les terroristes révolutionnaires, pleinement conscients de la nature illégale de leurs activités, sont tenus d'agir en stricte clandestinité. Ils se méfient ainsi de tout; même de ceux de leur propre milieu. De sorte que même le moindre bruissement est à éviter afin d'écarter toutes mauvaises surprises.

C'est ce qui donne, ainsi, cette grande liberté au narrateur qui se promène, presque sans restriction dans l'univers intérieur des personnages pour révéler aux lecteurs aussi fidèlement que faire se peut, ce qui se passe dans le for intérieur des acteurs des actions dans les deux textes.

Dans l'un ou l'autre cas, ce qui découle de l'analyse de récit de pensées dans $V$ ol de nuit aussi bien que La Condition humaine, donne accès à une nouvelle perspective intéressante d'apprécier les deux textes, ainsi que d'autres textes littéraires de la même orientation. Les révélations des intimités des personnages dans chacun des textes, permettent de creuser la profondeur de la signification des deux romans.

\section{Références}

Addo-Danquah, O. (2012) : "Narration et idéologie dans Comment cuisiner son mari à l'africaine de Calixthe Beyala », D. F. Edu-Buandoh \& A. B. Appartaim (eds.) Between Language and Literature. A Fetschrift for Professor Kofi Edu Yankson, University of Cape Coast Printing Press.

Addo-Danquah, O. (2002) : «De délices, déceptions, reveries...Une exploration de l'univers intérieur dans Longue est la nuit de Chichelle Tchivela ». D. D. Kuupole (ed.) An insight into Teaching and Learning of Languages in Contact in West Africa. Takoradi: St. Francis Press.

Angelet, C. \& Herman, J. (1993): «Narratologie ». M. Delcroix \& F. Hallyn (éds.) Introduction aux études littéraires. Paris : Klincksieck. 
Bakhtine, M. (1987) : Esthétique et théorie du roman. Paris : Gallimard.

Barthes, R. (1966): «Introduction à l'analyse structurale des récits», Communications 8. Paris : Seuil.

Buechner, F. (1973): Wishful Thinking. New York: Harper and Row.

Chardin, P. (dir.) (2002) : Autour du monologue intérieur. Paris : Atlantica-Ségnier.

Cohn, D. (1981) : Transparence intérieure. Paris : Seuil.

Dujardin, E. (2008) : Le monologue intérieur. Paris : Presses Universitaires Blaise Pascal.

Garnier, X. (2004) : «A quoi reconnaitt-on un récit initiatique ?»Poétique. Paris, Seuil.

Genette, G. (1972) : Figure III. Paris : Seuil.

Genette, G. (1983) : Nouveau Discours du récit. Paris: Seuil.

Humphrey, R. (1972): The Functions of Stream of Consciousness. J. L. Calderwood \& H. E. Toliver (eds.). Perspectives on Fiction. New York : Oxford University Press.

Jakobson, R. (1973) : Questions de poétique. Paris: Seuil.

Jacobson, R. (2017) : Essais de linguistique structurale. Paris : Encyclopaedia Universalis.

Philips, M. (1994) : Engaging Dreams : Perspectives on Flora Nwapa, Buchi Emecheta, Ama Atta Aidoo, Bessie Head and Titi Dangaremgba's Writing. A. Irele (ed.) Research in African Literature. Indiana: Indiana University Press, vol. 25 no. 4.

Queneau, R. (éd.) (1963) : Histoire des Littératures 3. Paris : Gallimard.

Rabatel, A. (1997) : Une histoire de point de vue. Paris : Klincksieck.

Rabatel, A. (1998) : La construction textuelle du point de vue. Paris : FeniXX.

Rabatel, A. (2008) : Homo narrans : pour une analyse énonciative et interactionnelle du récit. Limoges : Lambert-Lucas.

Todorov, T. (1966) : «Les catégories du récit littéraire ». Communications, 8. Paris : Seuil.

Todorov, T. (1973) : «Poétique ». O. Ducrot, T. Todorov, D. Sperber, M. Safouan, F. Wahl, Qu'est-ce que le structuralisme? Paris : Seuil.

Weismann, F. S. (1979) : Du monologue intérieur à la sous-conversation. Paris : Nizet. 